\title{
Crop water requirements of date palm based on actual applied water and Penman-Monteith calculations in Saudi Arabia
}

\author{
Abdulrasoul AL-Omran ${ }^{1} \cdot$ Samir Eid $^{2} \cdot$ Fahad Alshammari $^{1}$ \\ Received: 11 October 2016 / Accepted: 15 March 2019 / Published online: 8 April 2019 \\ (c) The Author(s) 2019
}

\begin{abstract}
This study was conducted in eight different regions of Saudi Arabia to estimate monthly and annual crop water requirements (CWR). Fields that have been selected are located in regions of the Medina (Al Ula), Tabuk (Teimaa), Makkah (Al Jumum), Al Jouf (Sakakah), Riyadh (Sodos), Qassim (Riyad Al Khabra), Hail (AL Kaedh), and East Region (Al Ahsa). The determination of CWRs was based on Penman Monteith method, field water balance, actual water applied in each field, and actual water applied by farmers in adjacent fields. The results based on Penman-Monteith method showed that the crop evapotranspiration, ETc (mm/year) of the sites in, Medina, Tabuk, Makkah, Al Jouf, Riyadh, Qassim, Hail, and East Region were 2418.75, 1940.51, 1837.76, 2259.03, 2139.23, 2207.41, 2008.23, and $2144.87 \mathrm{~mm} /$ year, respectively. The CWRs $\left(\mathrm{m}^{3} / \mathrm{ha}\right)$ after taking into account the proportion of cultivated area for each tree were: 9495.24, 7340.18, 7298.93, 8913.59, 8614.96, $8568.68,7996.99$, and $8510.72 \mathrm{~m}^{3} /$ ha, respectively. The average date palm numbers were 100 trees/ha. The total annual CWRs $\left(\mathrm{m}^{3} /\right.$ tree) in these sites were $95,73.4,73,89,86,85.7,80$, and $85 \mathrm{~m}^{3}$, respectively, as the radius of shaded area per tree is $3.5 \mathrm{~m}$ with an effective diameter of $90 \%$, and the rate of leaching was $12,8,13,12,14,11,13$, and 13\%, respectively. The average overall irrigation water requirements was $8342.41 \mathrm{~m}^{3} / \mathrm{ha} /$ year $(1$ ha. $=100$ trees $)$. The results of water balance method showed that the water consumed for Qassim and Al Jouf was 3604.31 and $3515.25 \mathrm{~m}^{3} / \mathrm{ha} / \mathrm{year}$, respectively. The actual irrigation water added by a flow meter for all study sites was 11,305.0, 9463.9, 9692.0, 11,252.75, 1007.40, 10,035.0, $10,272.5$, and $10,082.8 \mathrm{~m}^{3} / \mathrm{ha} /$ year, respectively, while these amounts added by the farmers in adjacent fields were 13,717 , $12,277,12,220,13,340,12,050,12,880,12,620$, and $12,610 \mathrm{~m}^{3} /$ ha/year, respectively.
\end{abstract}

Keywords Date palm $\cdot$ Evapotranspiration $\cdot$ Soil water content $\cdot$ Water requirements $\cdot$ Actual water requirements

\section{Introduction}

The agricultural expansion of date palm in Saudi Arabia faces huge challenges, which are typical of dry regions characterized with water scarcity, low rainfall and high evapotranspiration demand. Most of irrigation water is obtained from groundwater storage. The agricultural sector consumed more than $85 \%$ of water consumption, which reached more than 23 billion $\mathrm{m}^{3}$ in 2012 (Ministry of Electricity and Water

Abdulrasoul AL-Omran

rasoul@ksu.edu.sa

1 Department of Soil Sciences, College of Food and Agriculture Sciences, King Saud University, Riyadh 11451, Kingdom of Saudi Arabia

2 Agricultural Research Center, Agricultural Engineering Research Institute, Egypt (AEnRI), P. O. Box 256, Cairo, Dokki, Giza, Egypt
2014). Due to the increases of water demand, an effective and accurate evaluation of crop water requirement (CWR) is essential for planning, designing, operating, managing farm irrigation systems. Accurate estimation of CWR can help to maintain efficient use of water resources for irrigation. Evapotranspiration (ET) plays a major role in irrigation water management (Allen et al. 1998). They reported that many factors may play a role in limiting crop development; these are water availability, soil salinity, poor land fertility, poor soil and water management, plant density, and soil water contents. In Saudi Arabia, the limiting factor in agricultural development is water availability to irrigate the increasing number of date palm tree. Based on the recent statistical reports (General Authority for Statistics, 2015), the total number of date palm trees is 28.5 million on 54,000 ha drip irrigation and 53,200 ha surface irrigation fields.

For date palm ET estimation, the early work done by Furr and Armstrong (1956) estimated the annual ET to be 
1300-1600 mm, as reported by an excellent review on date palm water requirements (Carr 2012). In Saudi Arabia, estimation of water requirement of date palm has been reported by many researchers. These estimates differ between 6200 and $55,000 \mathrm{~m}^{3} / \mathrm{ha}$. Alazba (2001) estimates water requirement to be between 15,000 and $55,000 \mathrm{~m}^{3} / \mathrm{ha}$, depending on irrigation system or leaching requirement. Al-Ghobari (2000) has estimated the total annual amount of water required by one date palm tree as $136 \mathrm{~m}^{3}$ in Najran of south western region. Estimates of Alazba (2004) for the actual annual water use per one date palm tree were $137 \mathrm{~m}^{3}$ in Eastern region to about $195 \mathrm{~m}^{3}$ in the central region for flood irrigation, compared to $55 \mathrm{~m}^{3}$ and $78 \mathrm{~m}^{3} /$ tree for the two regions using drip irrigation, respectively. Kassem (2007) monitored water requirements in Qassim region, using soil water balance method, and he determined the annual water use with drip irrigation as $16,400 \mathrm{~m}^{3} / \mathrm{ha}$, with a density of 100 tree/ha. Al-Amoud et al. (2012) estimated the actual water use in the range between 21,360 and $28,290 \mathrm{~m}^{3} / \mathrm{ha}$, for density of 100 tree/ha. In study conducted in the western part of Saudi Arabia, Ismail et al. (2014) calculated water requirement based on Penman-Monteith for $\mathrm{ET}_{\mathrm{o}}, K_{\mathrm{c}}$ ranged from 0.8 and 1.0, and the evapotranspiration area $\left(23 \mathrm{~m}^{2} /\right.$ tree), to be $7300 \mathrm{~m}^{3} / \mathrm{ha}$, for density of 100 tree/ha. Recently, Dewidar et al. (2015) estimated water requirement of date palm using non-weighing lysimeter. They reported that volumetric palm water requirement per day fell between 87 and $297 \mathrm{~L} /$ day, with daily average of $182 \mathrm{~L}$, and crop coefficient ranged from 0.74 to 0.91 .

In Kuwait, date palm water requirement was determined using drainage-type lysimeters through water balance and ranged between 23,392 and $27,251 \mathrm{~m}^{3} /$ ha. The Sentek (Sentek Sensor Technologies) multisensory capacitance probe (EnviroScan Diviner 200) was used to measure soil water content within and below the root zone in the soil profile (Bhat et al., 2012). Al-Ghobari and El Marazky (2013) evaluated the accuracy of three commonly used soil water sensor types (an EnviroSCAN IRR.4-8 probe, a Watermark 200SS sensor and a tensiometer, model R), to monitor volumetric soil water content $(\theta \mathrm{v})$ and develop a means of improving irrigation scheduling; the results indicated that the tensiometers and Watermark sensors performed the best with the factory calibrations, with a RRMSE of 6.6, 7.6 and 8.5 , and 8.6, 11.1 and $11.0 \%$, respectively.

In Algeria, Mihoub et al. (2015) reported that the annual water requirement is $17,411 \mathrm{~m}^{3} / \mathrm{ha}$, for a density of 120 tree/ ha by drip irrigation compared to $26,117 \mathrm{~m}^{3}$ /ha of surface irrigation. In Jordan, Jordan valley, Mazahrih et al. (2012) reported that the amount of applied irrigation water per date palm tree was $27,40,53$ and $67 \mathrm{~m}^{3}$ for the irrigation treatments $50,75,100$ and $125 \% \mathrm{ET}_{\mathrm{c}}$, respectively.

The aim of present study was to: determine the date palm water requirements of eight regions of Saudi Arabia taking in the consideration the shaded area of the tree and irrigation water quality, and compare date palm water requirements with the actual water added by farmers in the eight regions.

\section{Materials and methods}

\section{Experimental sites}

This study was conducted in eight different regions of Saudi Arabia to estimate monthly and annual irrigation water requirements of date palm (Phoenix dactylifera L.) of Klayas variety. Field measurements and determination of ETc were taken during 1 year starting October 2013-September 2014 on complete grown tree (more than 10 years old). Fields that have been selected are located in regions of the Medina (Al Ula), Tabuk (Teimaa), Makkah (Al Jumum), Al Jouf (Sakakah), Riyadh (Sodos), Qassim (Riyad Al Khabra, Hail (AL Kaedh), and East Region (Al Ahsa) (Fig. 1). The geographical coordinates of each farm and characterization of the soil and irrigation water are shown in Tables 1 and 2.

\section{Metrological data}

Small weather stations were installed in each site of the study to monitor the changes of meteorological data during the study periods. The meteorological data recorded were: net radiation $\left(\mathrm{MJ} / \mathrm{m}^{2}\right.$ per day), wind speed $(\mathrm{m} / \mathrm{h})$, air temperature $\left({ }^{\circ} \mathrm{C}\right)$, relative humidity (\%), and rainfall (mm). The air water vapour pressure deficit $(\mathrm{kPa})$ was calculated using daily and hourly average temperatures and relative humidity. Finally, the reference evapotranspiration $\left(\mathrm{ET}_{\mathrm{r}}, \mathrm{mm} /\right.$ day) was calculated according to the Penman-Monteith (PM) equation as specified by the FAO protocol (Allen et al. 1998).

\section{Estimation method of evapotranspiration}

\section{Penman-Monteith method}

Using the Penman-Monteith equation (56) based on climate data on the farm as part of the national project of the rationalization of the irrigating water in agriculture (RIWA), Ministry of Environment, Water, Agriculture to estimate the water needs and then calculate the total irrigation water requirements based on the quality of irrigation water and soil salinity, taking into account the values of crop coefficient $K_{\mathrm{c}}$ for each month, irrigation efficiency and shaded area of date palm. The combined FAO Penman-Monteith method was used to calculate $\mathrm{ET}_{\mathrm{o}}$ through the following equation:

$\mathrm{ET}_{\mathrm{O}}=\frac{0.408 \Delta(\mathrm{Rn}-G)+\gamma\left(\frac{900}{T+273}\right) U_{2}\left(e_{\mathrm{s}}-e_{\mathrm{a}}\right)}{\Delta+\gamma\left(1+0.34 U_{2}\right)}$ 
Fig. 1 Location of date palm fields in eight different regions of Saudi Arabia

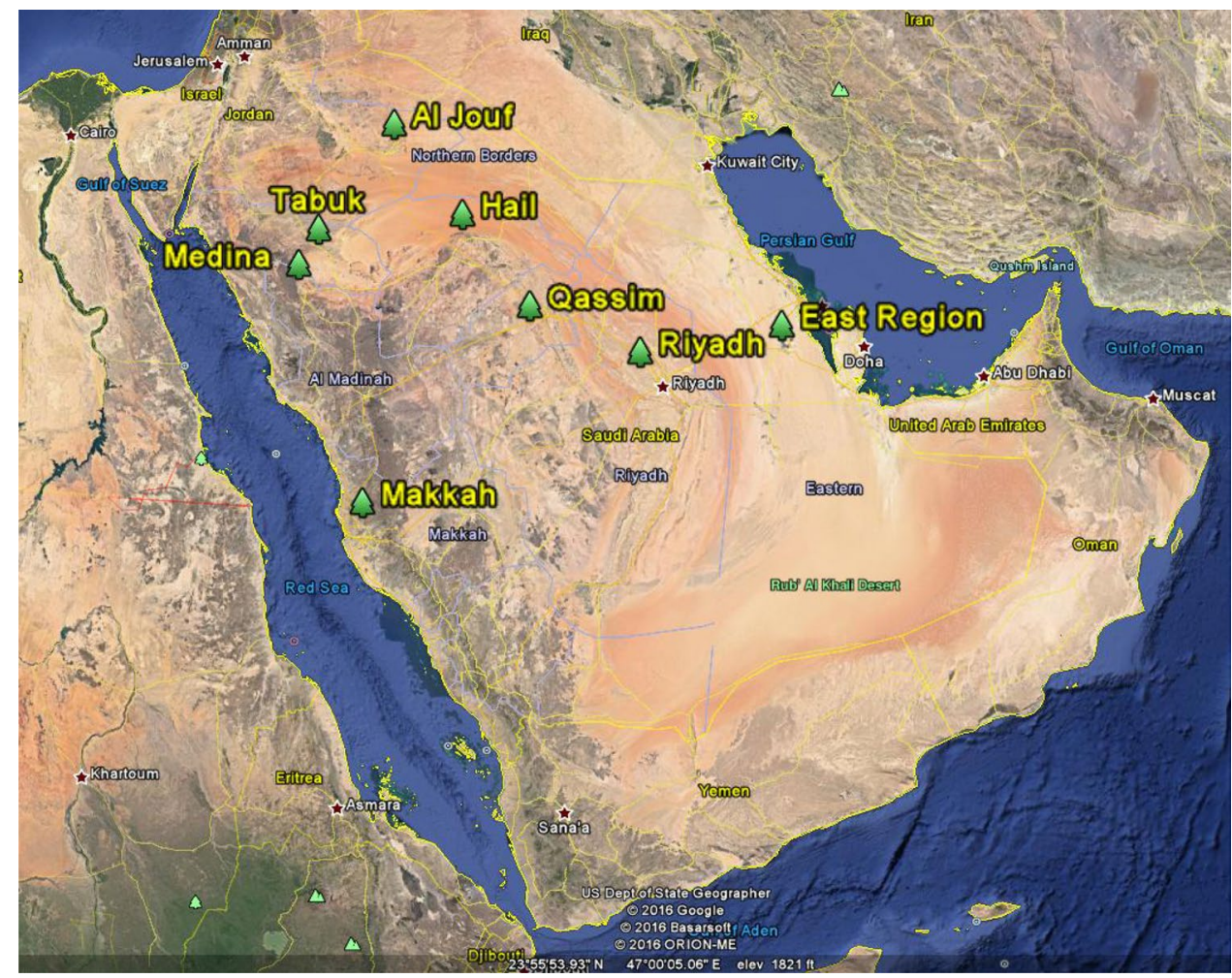

where $\mathrm{ET}_{\mathrm{o}}=$ reference evapotranspiration $(\mathrm{mm} / \mathrm{day})$, $\mathrm{Rn}=$ net radiation at the crop surface $\left(\mathrm{MJ} / \mathrm{m}^{2}\right.$ per day), $G=$ soil heat flux density $\left(\mathrm{MJ} / \mathrm{m}^{2}\right.$ per day), $T=$ mean daily air temperature at $2 \mathrm{~m}$ height $\left({ }^{\circ} \mathrm{C}\right), U_{2}=$ wind speed at $2 \mathrm{~m}$ height $(\mathrm{m} / \mathrm{s}), e_{\mathrm{s}}=$ saturation vapour pressure $(\mathrm{kPa})$, $e_{\mathrm{a}}=$ actual vapour pressure $(\mathrm{kPa}), e_{\mathrm{s}}-e_{\mathrm{a}}=$ saturation vapour pressure deficit $(\mathrm{kPa}), \Delta=$ slope of saturation vapour pressure curve at temperature $T\left(\mathrm{kPa} /{ }^{\circ} \mathrm{C}\right)$, and $\gamma=$ psychrometric constant $\left(\mathrm{kPa} /{ }^{\circ} \mathrm{C}\right)$

As crop evapotranspiration (ETc) can be calculated as

$\mathrm{ET}_{\mathrm{c}}=K_{\mathrm{c}} \times \mathrm{ET}_{\mathrm{r}}$

where $K_{\mathrm{c}}=$ crop coefficient ranged from 0.8 to 1.0 depending on the month of year as noted in (Allen et al. 1998), $\mathrm{ET}_{\mathrm{r}}=\mathrm{ET}_{\mathrm{o}}=$ Reference crop evapotranspiration $(\mathrm{mm} /$ day $)$, $\mathrm{ET}_{\mathrm{c}}=$ Crop evapotranspiration $(\mathrm{mm} /$ day $)$.

The percentage of evapotranspiration area $\left(S_{\mathrm{e}}\right)$ was calculated from actual shaded area at noon in June (representing maximum net radiation time) to the actual area to each tree from the following equation as described by Hellman (2010) for grape:

$S_{\mathrm{e}}=\frac{\text { Shaded area per tree }}{\text { Actual area }} \times 100=\frac{\pi R^{2}}{10 \mathrm{~m} \times 10 \mathrm{~m}} \times 100$

where $S_{\mathrm{e}}=$ the percentage of evapotranspiration area, $R=$ radius of tree $(\mathrm{m})$, and shaded area $=$ area of the shade of one tree measured at noon.
Leaching requirements were calculated using the following equation (Doorenbos and Pruitt 1977).

$\mathrm{LR}=\frac{\mathrm{EC}_{\mathrm{iw}}}{2 \mathrm{MaxEC}_{\mathrm{e}}} \times \frac{1}{\mathrm{Eff}}$

where $\mathrm{LR}=$ the fraction of the water to be applied that passes through the entire root zone depth and percolates below. $\mathrm{EC}_{\mathrm{iw}}=$ electrical conductivity of irrigation water $(\mathrm{dS} / \mathrm{m})$. $\mathrm{EC}_{\mathrm{e}}=$ electrical conductivity of the soil saturation extract for a given crop appropriate to the tolerable degree of yield reduction $(\mathrm{dS} / \mathrm{m})$. Max $\mathrm{EC}_{\mathrm{e}}=$ maximum tolerable electrical conductivity of the soil saturation extract for a given crop $(\mathrm{dS} / \mathrm{m})$. Eff $=$ leaching efficiency $(90 \%$ for sandy and loamy sands).

The gross water requirements (GWR) were calculated using the following equation:

$\mathrm{GWR}=\frac{\mathrm{ET}_{\mathrm{c}} \times S_{\mathrm{e}}}{(1-\mathrm{LR}) \times \mathrm{Effir}}$

where GWR $=$ gross water requirement $\left(\mathrm{m}^{3} / \mathrm{ha}\right), \mathrm{ET}_{\mathrm{c}}=\mathrm{crop}$ evapotranspiration $\left(\mathrm{m}^{3} / \mathrm{ha}\right)$, Effir $=$ efficiency $(\%), 90 \%$, $\mathrm{LR}=$ leaching requirements, and $S_{\mathrm{e}}=$ the percentage of evapotranspiration area. 


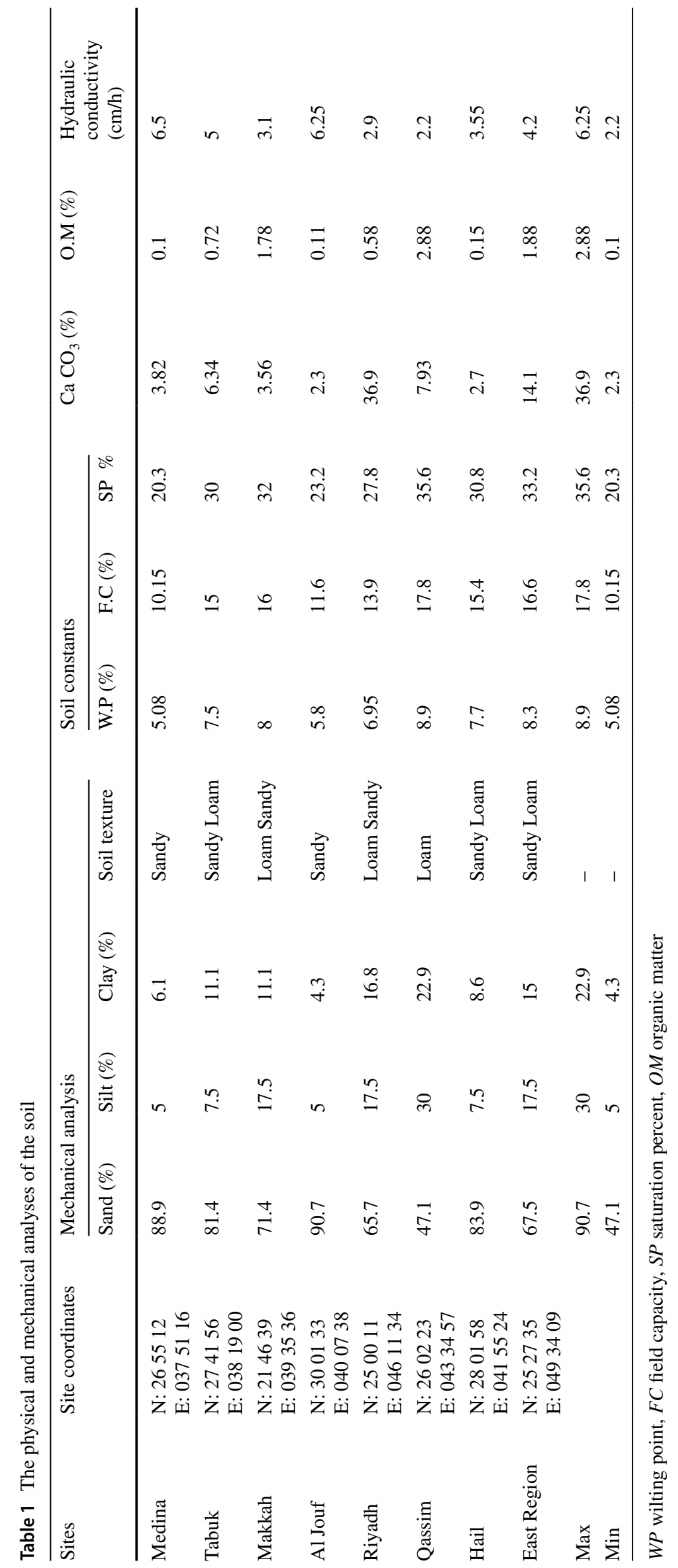


Table 2 The analyses of the irrigation water

\begin{tabular}{|c|c|c|c|c|c|c|c|c|c|c|c|c|c|}
\hline \multirow[t]{2}{*}{ Sites } & \multirow[t]{2}{*}{ Site coordinates } & \multirow[t]{2}{*}{$\mathrm{EC}(\mathrm{dm} / \mathrm{m})$} & \multirow[t]{2}{*}{ TDS } & \multirow[t]{2}{*}{ SAR } & \multirow[t]{2}{*}{$\mathrm{pH}$} & \multirow[t]{2}{*}{$\mathrm{EC}(\mathrm{dm} / \mathrm{m})$} & \multicolumn{3}{|c|}{ Cation (meq/l) } & \multicolumn{4}{|c|}{ Anion (meq//l) } \\
\hline & & & & & & & $\mathrm{Mg}^{++}$ & $\mathrm{Na}^{+}$ & $\mathrm{K}^{+}$ & $\overline{\mathrm{CO}_{3}^{=}}$ & $\mathrm{HCO}_{3}^{-}$ & $\mathrm{Cl}^{-}$ & $\mathrm{SO}_{4}^{=}$ \\
\hline Medina & $\begin{array}{l}\mathrm{N}: 265512 \\
\mathrm{E}: 03751 \quad 16\end{array}$ & 0.85 & 544 & 3.35 & 7.63 & 0.85 & 1.1 & 4.8 & 0.15 & 0 & 1.6 & 5.0 & 2.5 \\
\hline Tabuk & $\begin{array}{l}\mathrm{N}: 274156 \\
\mathrm{E}: 0381900\end{array}$ & 0.61 & 390 & 2.23 & 7.6 & 0.61 & 1.9 & 3.11 & 0.12 & 0 & 1.5 & 3.0 & 2.5 \\
\hline Makkah & $\begin{array}{l}N: 214639 \\
\text { E: } 0393536\end{array}$ & 1.57 & 1004 & 3.31 & 7.5 & 1.57 & 2.9 & 6.62 & 0.21 & 0 & 2.0 & 7.5 & 6.0 \\
\hline Al Jouf & $\begin{array}{l}\mathrm{N}: 300133 \\
\mathrm{E}: 0400738\end{array}$ & 1.5 & 960 & 4.15 & 7.4 & 1.5 & 2.6 & 7.81 & 0.15 & 0 & 2.0 & 8.1 & 5.2 \\
\hline Riyadh & $\begin{array}{l}\mathrm{N}: 250011 \\
\mathrm{E}: 0461134\end{array}$ & 1.01 & 646 & 3.42 & 7.61 & 1.01 & 1.98 & 5.4 & 0.18 & 0 & 2.1 & 5.1 & 4.8 \\
\hline Qassim & $\begin{array}{l}N: 260223 \\
E: 0433457\end{array}$ & 2.4 & 1536 & 8.44 & 7.8 & 2.4 & 3.0 & 16.99 & 0.30 & 0 & 2.76 & 16.88 & 5.12 \\
\hline Hail & $\begin{array}{l}\text { N: } 280158 \\
\text { E: } 0415524\end{array}$ & 0.94 & 601 & 3.45 & 7.6 & 0.94 & 1.0 & 5.0 & 0.20 & 0 & 2.1 & 5.1 & 2.6 \\
\hline East Region & $\begin{array}{l}\text { N: } 252735 \\
\text { E: } 0493409\end{array}$ & 1.56 & 998 & 3.66 & 7.5 & 1.56 & 3.0 & 7.5 & 0.25 & 0 & 2.6 & 7.0 & 6.5 \\
\hline
\end{tabular}

\section{Water balance method}

Water balance method was used to calculate the difference in soil moisture content between two irrigations by measuring changes in moisture content after and before irrigation at the root zone using a device to measure moisture (Terra Sen Dacom) at depths of 10-120 cm all year, after verifying the accuracy of moisture sensitive, calibrated sensors with direct method (gravimetric laboratory method) with data from the sensors for a period of 2 months for three sites. The total amount of irrigation was calculated by the following equation:

$\mathrm{ET}=P+I-\mathrm{Dr} \pm \Delta S$

where ET $=$ consumptive use $\mathrm{mm}, P=$ precipitation $(\mathrm{mm})$, $I=$ irrigation added $(\mathrm{mm}), \mathrm{Dr}=$ drainage $(\mathrm{mm})$, and $\Delta S=$ change in soil water content $(\mathrm{mm})$

\section{The amount of applied irrigation water}

a. The study site: The amount of applied irrigation water throughout the year was determined by recording the readings of flow meter (actually added) in the field experiment using soil moisture and data of meteorological stations.

b. Farmers fields: The amount of applied irrigation water throughout the year was determined by recording readings of flow meter in adjacent farms (actually added to the fields by farmers adjacent to the field of study).

\section{Results and discussion}

\section{Climatic conditions in the experimental site}

The observed average values of the climatic variables in the eight sites are presented in Table 3. The data revealed that the highest maximum temperature during the year in the Makkah and East Region were 49.9 and $47.5^{\circ} \mathrm{C}$, while the lowest minimum temperature during the year in the Tabuk and Hail was -3.3 and $-2.4{ }^{\circ} \mathrm{C}$, respectively. The highest maximum net radiation during the year in the Medina and $\mathrm{Al}$ Jouf was 11.22 and $10.89 \mathrm{MJ} / \mathrm{m}^{2}$, while the lowest minimum net radiation during the year in the Al Jouf and Hail was 0.46 and $0.76 \mathrm{MJ} / \mathrm{m}^{2}$, respectively. The highest maximum relative humidity during the year in the Hail and Al Jouf was 95 and $92 \%$, respectively, while the lowest minimum relative humidity during the year in the Al Jouf was $4 \%$. The highest maximum wind speed during the year in the $\mathrm{Al}$ Jouf and Medina was 6.5 and $5.1 \mathrm{~m} / \mathrm{s}$, while the lowest minimum wind speed during the year in the Tabuk and Medina was 0.2 and $0.4 \mathrm{~m} / \mathrm{s}$, respectively. The results of the study showed that the crop evapotranspiration, ETc, (mm/year) of the sites in Medina, Tabuk, Makkah, Al Jouf, Riyadh, Qassim, Hail, and East Region was 2418.75, 1940.51, 1837.76, 2259.03, 2139.23, 2207.41, 2032.09, and $2144.87 \mathrm{~mm} /$ year, respectively. These results indicate that the estimation of ETc in different sites of Saudi Arabia is affected by weather conditions. The highest value of ETc was in Medina field site which is due to the highest net radiation and temperatures. 
Table 3 The observed average values of the climatic variables in eight sites

\begin{tabular}{|c|c|c|c|c|c|c|c|c|c|c|c|}
\hline Sites & Stat & T-Mean $\left({ }^{\circ} \mathrm{C}\right)$ & T-max $\left({ }^{\circ} \mathrm{C}\right)$ & $\mathrm{T}-\min \left({ }^{\circ} \mathrm{C}\right)$ & Rainfall (mm) & $\begin{array}{l}\text { Radia- } \\
\text { tion }(\mathrm{MJ} / \\
\left.\mathrm{m}^{2}\right)\end{array}$ & RH-min (\%) & $\begin{array}{l}\text { Wind } \\
\text { speed } \\
(\mathrm{m} / \mathrm{s})\end{array}$ & $\mathrm{ET}_{0}(\mathrm{~mm})$ & $K_{\mathrm{c}}^{\mathrm{a}}$ & ETc $(\mathrm{mm})$ \\
\hline \multirow[t]{3}{*}{ Medina } & Min. & 9.30 & 13.50 & 2.80 & 0.00 & 2.05 & 6.00 & 0.40 & 2.23 & 0.80 & 1.78 \\
\hline & Max. & 34.40 & 40.10 & 30.30 & 0.60 & 11.22 & 44.00 & 5.10 & 12.21 & 1.00 & 12.21 \\
\hline & Ave. & 24.34 & 30.51 & 17.81 & 0.00 & 8.19 & 16.51 & 2.53 & 7.11 & 0.91 & 6.63 \\
\hline \multirow[t]{3}{*}{ Tabuk } & Min. & 5.60 & 9.50 & -3.30 & 0.00 & 0.79 & 6.00 & 0.20 & 1.18 & 0.80 & 0.94 \\
\hline & Max. & 33.20 & 41.80 & 26.30 & 8.00 & 9.76 & 75.00 & 4.20 & 10.57 & 1.00 & 10.57 \\
\hline & Ave. & 21.67 & 28.72 & 14.35 & 0.11 & 7.23 & 18.47 & 1.95 & 5.72 & 0.91 & 5.32 \\
\hline \multirow[t]{3}{*}{ Makkah } & Min. & 20.20 & 23.90 & 13.10 & 0.00 & 1.81 & 6.00 & 0.50 & 2.43 & 0.80 & 1.94 \\
\hline & Max. & 39.50 & 49.90 & 32.00 & 12.80 & 9.15 & 58.00 & 2.80 & 8.40 & 1.00 & 8.40 \\
\hline & Ave. & 30.36 & 37.71 & 23.77 & 0.04 & 6.67 & 23.27 & 1.36 & 5.46 & 0.91 & 5.03 \\
\hline \multirow[t]{3}{*}{ Al Jouf } & Min. & 4.10 & 7.00 & -1.60 & 0.00 & 0.46 & 4.00 & 0.80 & 0.75 & 0.80 & 0.60 \\
\hline & Max. & 37.50 & 43.60 & 32.30 & 42.00 & 10.89 & 92.00 & 6.50 & 15.65 & 1.00 & 15.65 \\
\hline & Ave. & 22.47 & 28.62 & 15.93 & 0.38 & 7.45 & 22.05 & 2.72 & 6.59 & 0.91 & 6.19 \\
\hline \multirow[t]{3}{*}{ Riyadh } & Min. & 7.40 & 10.70 & -0.70 & 0.00 & 1.17 & 5.00 & 0.50 & 1.22 & 0.80 & 0.98 \\
\hline & Max. & 37.10 & 44.10 & 30.70 & 16.60 & 10.00 & 87.00 & 4.30 & 12.72 & 1.00 & 12.72 \\
\hline & Ave. & 24.90 & 31.81 & 16.95 & 0.26 & 7.52 & 17.73 & 1.91 & 6.29 & 0.91 & 5.86 \\
\hline \multirow[t]{3}{*}{ Qassim } & Min. & 6.00 & 9.90 & -1.90 & 0.00 & 1.41 & 5.00 & 0.70 & 1.51 & 0.80 & 1.21 \\
\hline & Max. & 38.00 & 45.70 & 30.50 & 13.40 & 9.08 & 76.00 & 5.00 & 13.34 & 1.00 & 12.74 \\
\hline & Ave. & 25.12 & 32.80 & 16.82 & 0.08 & 6.90 & 17.58 & 2.23 & 6.50 & 0.91 & 6.05 \\
\hline \multirow[t]{3}{*}{ Hail } & Min. & 4.80 & 7.30 & -2.40 & 0.00 & 0.76 & 7.00 & 0.40 & 0.76 & 0.80 & 0.61 \\
\hline & Max. & 37.10 & 43.80 & 31.20 & 30.40 & 10.81 & 95.00 & 4.80 & 10.43 & 1.00 & 10.43 \\
\hline & Ave. & 22.31 & 29.50 & 15.08 & 0.54 & 7.51 & 22.32 & 2.14 & 5.90 & 0.91 & 5.50 \\
\hline \multirow[t]{3}{*}{ East Region } & Min. & 9.10 & 14.40 & 0.50 & 0.00 & 0.88 & 6.00 & 0.60 & 1.16 & 0.80 & 0.90 \\
\hline & Max. & 39.20 & 47.50 & 32.70 & 26.80 & 10.28 & 89.00 & 4.80 & 12.69 & 1.00 & 12.70 \\
\hline & Ave. & 25.60 & 34.28 & 18.81 & 0.40 & 6.98 & 20.96 & 2.08 & 6.30 & 0.91 & 5.88 \\
\hline
\end{tabular}

${ }^{a} K_{\mathrm{c}}$ values are based on studies of Al-Amoud et al. (2012) and Ismail et al. (2014)

\section{Date palm water requirement in the experimental sites}

\section{Using the Penman-Monteith equation (56) based on climate data}

The results of the study in Table 4 show that the irrigation water requirements $\left(\mathrm{m}^{3} / \mathrm{ha}\right)$ after taking into account the proportion of cultivated area for each tree of the sites in Medina, Tabuk, Makkah, Al Jouf, Riyadh, Qassim, Hail, and East Region were 9495.24, 7340.18, 7298.93, 8913.59,

Table 4 Comparison between Penman-Monteith calculations and actual amount of applied water in the different sites, and increase in water ratio (\%) compared to Penman-Monteith method

\begin{tabular}{|c|c|c|c|c|c|c|}
\hline \multirow[t]{2}{*}{ Site } & \multirow[t]{2}{*}{$\begin{array}{l}\text { Penman-Monteith } \\
\text { method }\left(\mathrm{m}^{3} / \text { ha/year }\right)\end{array}$} & \multirow[t]{2}{*}{$\begin{array}{l}\text { Water balance method } \\
\left(\mathrm{m}^{3} / \mathrm{ha} / \text { year }\right)\end{array}$} & \multicolumn{2}{|c|}{ Actual applied water $\left(\mathrm{m}^{3} /\right.$ ha/year $)$} & \multicolumn{2}{|c|}{$\begin{array}{l}\text { The increase in water ratio }(\%) \\
\text { compared to Penman-Monteith } \\
\text { method }\end{array}$} \\
\hline & & & Field study & Farmer adjacent & Field study & Farmer adjacent \\
\hline Medina & 9495 & - & 11,305 & 13,717 & 16.0 & 30.8 \\
\hline Tabuk & 7340 & - & 9463 & 12,277 & 22.4 & 40.2 \\
\hline Makkah & 7298 & - & 9692 & 12,220 & 24.7 & 40.3 \\
\hline Al Jouf & 8913 & 3515 & 11,252 & 13,340 & 20.8 & 33.2 \\
\hline Riyadh & 8614 & - & 10,007 & 12,050 & 13.9 & 28.5 \\
\hline Qassim & 8568 & 3604 & 10,035 & 12,880 & 14.6 & 33.5 \\
\hline Hail & 7996 & - & 10,272 & 12,620 & 21.2 & 36.6 \\
\hline East Region & 8510 & - & 10,082 & 12,610 & 15.6 & 32.5 \\
\hline
\end{tabular}


$8614.96,8568.68,7996.99$, and $8510.72 \mathrm{~m}^{3} / \mathrm{ha}$, respectively, with 100 palm trees/ha. The total annual irrigation water requirements $\left(\mathrm{m}^{3} /\right.$ tree $)$ in these sites were $95,73.4,73,89$, $86,85.7,80$, and $85 \mathrm{~m}^{3}$, respectively, as the radius of shaded area per tree is $3.5 \mathrm{~m}$ with effective diameter of $90 \%$, and the rate of leaching was: $12,8,13,12,14,11,13$, and $13 \%$, respectively. Irrigation efficiency was $90 \%$ and found that the average overall irrigation water requirements in all sites were $8342.41 \mathrm{~m}^{3} / \mathrm{ha} / \mathrm{year}$ with 100 (tree/ha). These values of ETc and CRW are attributed to the metrological conditions of each site. However, the reduction in the estimated CWR to an average of $8342 \mathrm{~m}^{3} /$ ha compared to overall average of $20,000 \mathrm{~m}^{3} /$ ha as reported by many researchers (Al-Amoud et al. 2012; Ismail et al. 2014; Mihoub et al. 2015; Dewidar et al. 2015) is mainly attributed to the percentage of vegetative cover or shaded area $\left(S_{\mathrm{e}}\right)$ of the tree, as we calculated the Se values as (0.33) of the actual area of the tree. Therefore, the practice calculating crop water requirements based on a distance of $10 \mathrm{~m} \times 10 \mathrm{~m}$ between trees in the farms of Saudi Arabia is not adequate in all sites. This area of $100 \mathrm{~m}^{2}$ for each tree usually overestimates the crop water requirements, and therefore, calculations of crop water requirements are shown to be based on actual vegetation (shaded) area that was found to be around $7 \mathrm{~m} \times 7 \mathrm{~m}$ in our study. This practice will ensure higher vegetative cover in date palm farms and better estimates of actual crop water requirements.

\section{Water balance method}

The results of water balance method showed that the relationship between the data of Terra Sen Dacom sensors and direct method (Gravimetric Method) in Fig. 2 for a period of 2 months for the three sites is a linear relationship with $r^{2}=0.90-0.93$, and the results of Table 4 show that the water consumed is 3604.31 and $3515.25 \mathrm{~m}^{3} / \mathrm{ha} /$ year for Qassim and Al Jouf, respectively. The amount of rainfall for Qassim and Al Jouf during the season was 92.85 and $434.99 \mathrm{~m}^{3} /$ ha/year, respectively. The water balance methods showed that water consumption for the two sites was very low compared to ETc estimation by PM method or water added to field. This reduction in total amount of water consumption is mainly due to short depth of the sensor installed in the site $(120 \mathrm{~cm})$. It seems that $50 \%$ of water added to date palm tree considered as leaching water.

\section{The amount of applied irrigation water used in study sites}

Table 4 shows that the amount of irrigation water actually added by a flow meter of all study sites of the Medina, Tabuk, Makkah, Al Jouf, Riyadh, Qassim, Hail, and East Region was 11,305.0, 9463.9, 9692.0, 11,252.75, 1007.4, 10,035.0, $10,272.5$, and $10,082.8 \mathrm{~m}^{3} / \mathrm{ha} / \mathrm{year}$, while these amounts added by the farmers in adjacent farms was $13,717,12,277$,

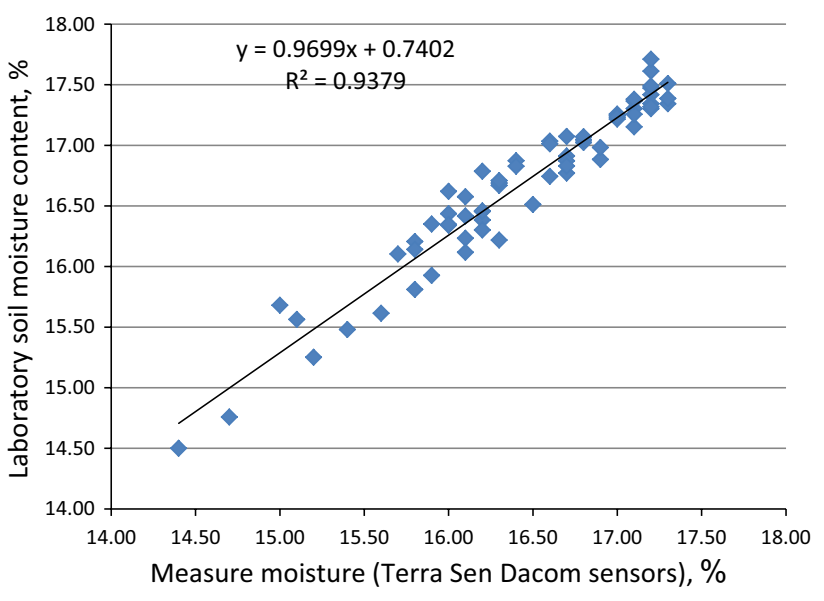

Fig. 2 Relation between laboratory soil moisture content and the measured soil moisture content (Terra Sen Dacom sensors)

$12,220,13,340,12,050,12,880,12,620$, and $12,610 \mathrm{~m}^{3} / \mathrm{ha} /$ year, respectively. The increases in the amount of irrigation in adjacent farms by the farmers are mainly due to poor knowledge on irrigation requirements. Before installing the system of monitoring irrigation water in the study sites, the farmers used to add three times this amount and it might reached $35,000 \mathrm{~m} 3 / \mathrm{ha}$.

\section{Water use efficiency and water saving}

Table 5 shows that the productivity per hectare ranged between $5406 \mathrm{~kg} / \mathrm{ha}$ in Makkah and $8400 \mathrm{~kg} / \mathrm{ha} \mathrm{Al} \mathrm{Ahsa,} \mathrm{and} \mathrm{water}$ use efficiency of palm in Medina, Tabuk, Makkah, Al Jouf, Riyadh, Qassim, Hail, and East Region in study sites was 0.66, $0.66,0.56,0.55,0.76,0.67,0.67$, and $0.83 \mathrm{~kg} / \mathrm{m}^{3}$, respectively, while in the neighbouring fields, these values were $0.54,0.50$, $0.44,0.46,0.62,0.51,0.53$, and $0.68 \mathrm{~kg} / \mathrm{m}^{3}$, respectively. The water saving was $17.58,22.91,20.69,15.65,16.95,22.09$, 18.60 , and $20.04 \%$, respectively.

Based on the equation by Mass and Hoffman (1977) (Yield $\%=100-\mathrm{b}\left(\mathrm{EC}_{\mathrm{e}-\mathrm{a}}\right)$, on the reduction of yield using saline water in all sites of the study. For the date palm tree, the threshold salinity values (a) of date palm are $4.0 \mathrm{dS} / \mathrm{m}$ and (b) as $3.6 \%$. The results in Table 5 show that date palm production was affected by salinity in Al-Qassim site with a reduction $25 \%$ followed by East Region farm at $7.31 \%$. All other areas were not affected by salinity.

\section{Conclusions}

This study was conducted in eight different date palm regions of Saudi Arabia to estimate monthly and annual irrigation water requirements. The regions that have been selected are located in Medina (Al Ula), Tabuk (Teimaa), 
Table 5 Water use efficiency $\mathrm{Kg} / \mathrm{m}^{3}$, yield $\mathrm{Kg} / \mathrm{ha}$ and water saving ( \%) in the field study compared to farmer adjacent

\begin{tabular}{|c|c|c|c|c|c|c|c|c|c|}
\hline \multirow[t]{2}{*}{ Sites } & \multicolumn{3}{|l|}{ Field study } & \multicolumn{3}{|l|}{ Farmer adjacent } & \multirow[t]{2}{*}{ Water saving (\%) } & \multirow[t]{2}{*}{$\mathrm{EC}_{\mathrm{e}}$} & \multirow[t]{2}{*}{ Yield (\%) } \\
\hline & $\begin{array}{l}\text { Water applied } \\
\left(\mathrm{m}^{3} / \text { ha/year }\right)\end{array}$ & Yield (kg/ha) & $\begin{array}{l}\text { Water use } \\
\left(\mathrm{kg} / \mathrm{m}^{3}\right)\end{array}$ & $\begin{array}{l}\text { Water applied } \\
\left(\mathrm{m}^{3} / \text { ha/year }\right)\end{array}$ & Yield (kg/ha) & $\begin{array}{l}\text { Water use } \\
\left(\mathrm{kg} / \mathrm{m}^{3}\right)\end{array}$ & & & \\
\hline Medina & 11,305 & 7482 & 0.66 & 13,717 & 7374 & 0.54 & 17.58 & 1.000 & 100.00 \\
\hline Tabuk & 9463 & 6240 & 0.66 & 12,277 & 6170 & 0.50 & 22.91 & 0.935 & 100.00 \\
\hline Makkah & 9692 & 5406 & 0.56 & 12,220 & 5324 & 0.44 & 20.69 & 4.600 & 97.84 \\
\hline Al Jouf & 11,252 & 6215 & 0.55 & 13,340 & 6150 & 0.46 & 15.65 & 4.840 & 96.98 \\
\hline Riyadh & 10,007 & 7620 & 0.76 & 12,050 & 7520 & 0.62 & 16.95 & 2.050 & 100.00 \\
\hline Qassim & 10,035 & 6742 & 0.67 & 12,880 & 6531 & 0.51 & 22.09 & 10.950 & 74.98 \\
\hline Hail & 10,272 & 6908 & 0.67 & 12,620 & 6708 & 0.53 & 18.60 & 2.600 & 100.00 \\
\hline East Region & 10,082 & 8400 & 0.83 & 12,610 & 8520 & 0.68 & 20.04 & 6.030 & 92.69 \\
\hline
\end{tabular}

Makkah (Al Jumum), Al Jouf (Sakakah), Riyadh (Sodos), Qassim (Riyad Al Khabra, Hail (AL Kaedh), and East Region (Al Ahsa). The results of the study showed that the crop evapotranspiration, ETc (mm/year), without taking shaded area per tree of Medina, Tabuk, Al Jouf, Riyadh, Qassim, Hail, and Al Ahsa was 2418.75, 1940.51, 1837.76, $2259.03,2139.23,2207.41,2032.09$, and $2144.87 \mathrm{~mm} /$ year, respectively. The irrigation water requirements $\left(\mathrm{m}^{3} /\right.$ ha) after taking into account the proportion of cultivated area for each year are 9495.24, 7340.18, 7298.93, 8913.59, $8614.96,8568.68,7996.99$, and $8510.72 \mathrm{~m}^{3} / \mathrm{ha}$, respectively, $100 \mathrm{Palm} / \mathrm{ha}$, and the annual total irrigation water requirements $\left(\mathrm{m}^{3} /\right.$ tree $)$ in these regions were $95,73.4,73$, $89,86,85.7,80$, and $85 \mathrm{~m}^{3}$, respectively, as the radius of shaded area per tree is $3.5 \mathrm{~m}$. The decrease in the CRW in all sites of study to around $8000 \mathrm{~m}^{3} /$ ha is mainly attributed to percentage of shaded area of date palm tree. Therefore, the practice of calculations of CRW based on a distance between trees to $10 \mathrm{~m} \times 10 \mathrm{~m}$ should be changed to calculations based on actual vegetation area, which is an average of $7 \mathrm{~m} \times 7 \mathrm{~m}$ in order to avoid overestimation of CRW of date palm trees. The water balance methods showed that water consumption for the two sites was very low compared to ETc estimation by PM method or water added to field. This reduction in total amount of water consumption is mainly due to short depth of the sensor installed in the site $(120 \mathrm{~cm})$. It seems that $50 \%$ of water added to date palm tree considered as leaching water.

Acknowledgement The authors wish to thank King Saud University, Deanship of Scientific Research, College of Food and Agriculture Science, Research Center, for supporting the research work.

Open Access This article is distributed under the terms of the Creative Commons Attribution 4.0 International License (http://creativeco mmons.org/licenses/by/4.0/), which permits unrestricted use, distribution, and reproduction in any medium, provided you give appropriate credit to the original author(s) and the source, provide a link to the Creative Commons license, and indicate if changes were made.

\section{References}

Al-Amoud AI, Mohammed FS, Saad AA, Alabdulkader AM (2012) Reference evapotranspiration and date palm water use in the Kingdom of Saudi Arabia. Int Res J Agric Sci Soil Sci 2(4):155-169

Alazba AA (2001) Theoretical estimate of palm water requirements using Penman-Monteith model. In: A paper number 12100, 2001 ASAE annual meeting

Alazba AA (2004) Estimating palm water requirements using Penman-Monteith mathematical model. J King Saud Univ Agric Sci 16(2):137-152

Al-Ghobari HM (2000) Estimation of reference evapotranspiration for southern region of Saudi Arabia. Irrig Sci 19:81-86

Al-Ghobari HM, El Marazky MSA (2013) Field evaluation of EnviroSCAN performance for monitoring soil water content compared with other soil moisture sensors under arid conditions. Wulfenia J Klagenf Austria 20(4):54-70

Allen RG, Pereira LS, Raes D, Smith M (1998) Crop evapotranspiration. FAO irrigation and drainage paper no. 56, FAO, Rome, Italy

Bhat NRVS, Lekha MK, Suleiman B, Thomas SI, Ali P George, AlMulla L (2012) Estimation of Water requirements for young date palms under arid climatic conditions of Kuwait. World J Agric Sci 8(5):448-452

Carr MKV (2012) The water relation and irrigation requirements of date palm (Phoenix dactylifera L.): a review. Exp Agric 49(1):91-113

Dewidar AZ, Ben Abdallah A, Al-Fuhaid Y, Essafi B (2015) Lysimeter based water requirements and crop coefficient of surface dripirrigated date palm in Saudi Arabia. Int Res J Agric Sci Soil Sci 5(7):173-183

Doorenbos J, Pruitt WO (1977) Crop water requirement. FAO Irrigation and drainage paper no. 24 FAO, Rome, Italy

Furr JR, Armstrong WW (1956) The seasonal use of water by Khadrawy date palm. Date Grower's Inst Rep 23:5-7

General Authority for Statistics (2015) Detailed results of the Agriculture Census. Kingdom of Saudi Arabia, stats.gov.sa

Hellman E (2010) Irrigation scheduling of grapevines with evapotranspiration data. Texas A\&M University, Texas AgriLife Extension Service: College Station, Texas. http://winegrapes.tamu.edu/ grow/irrigationscheduling.pdf

Ismail SM, Al-Qurashi AD, Awad AA (2014) Optimization of irrigation water use, yield, and quality of Nabbut-Saif date palm under dry land conditions. Irrig Drain 63:29-37 
Kassem MA (2007) Water requirements and crop coefficient of date palm trees Sukariah CV. Misr J Agric Eng 24(2):339-359

Mass EV, Hoffman GH (1977) Crop salt tolerance-current assesment. Irrig Drainage Div ASCE 103:115-134

Mazahrih NT, Al-Zubi Y, Ghnaim H, Lababdeh L, Ghananeem M, Ahmadeh HA (2012) Determination actual evapotranspiration and crop coefficients of date palm trees (Phoenix dactylifera) in the Jordan Valley. Am Eurasian J Agric Environ Sci 12(4):434-443

Mihoub A, Helimi S, Mokhtari S, Kharaz E, Koull N, Lakhdari K, Benzaoui T, Bougafla A, Laouisset M, Kherfi Y, Halitim A (2015) Date palm (Phoenix dactylifera $\mathrm{L}$.) irrigation water requirements as affected by salinity in Oued Righ conditions, North Eastern Sahara, Algeria. Asian J Crop Sci 7(3):174-185

Ministry of Electricity and Water (2014) Statistical annual report Riyadh, Saudi Arabia

Publisher's Note Springer Nature remains neutral with regard to jurisdictional claims in published maps and institutional affiliations. 